\title{
Siniketun taloudellisesti tärkeiden ominaisuuksien geenikartoitus
}

\author{
Kari Elo, Sanna Keski-Nisula, Jaana Tähtinen, Hilppa Hietanen ja Matti Ojala
}

Kotieläintieteen laitos, PL 28,00014 Helsingin yliopisto, kari.elo@helsinki.fi

Siniketulle laadittiin geneettinen kytkentäkartta käyttäen mikrosatelliittimerkkejä. Yhteensä 130 koiran mikrosatelliittimerkin toimivuus ja muuntelun määrä testattiin siniketulla. Näistä merkeistä 102 voitiin genotyypittää kartoituspopulaatiossa. Kartoituspopulaatio koostui kolmen sukupolven aineistosta. Lähtöpopulaatiossa neljä urosta paritettiin 16 naaraan kanssa. Näiden jälkeläisistä (F1) paritettiin 10 urosta 33 naaraan kanssa kahtena peräkkäisenä vuotena. F2 -sukupolvessa oli 392 jälkeläistä. Yhteensä kartoituspopulaatiossa oli yksilöitä 455. Laaditussa kytkentäkartassa on 87 merkkiä 17 kytkentäryhmässä ja kartan kokonaispituus on 1658 senttiMorgania (cM). Kytkentäkartat laskettiin kummallekin sukupuolelle erikseen sekä keskiarvokarttana. Yksittäisten kytkentäryhmien pituudet sukupuolten keskiarvokartassa vaihtelivat 4,9-322,2 cM välillä.

Taloudellisesti tärkeistä ominaisuuksista tutkittiin eläimen kokoa ja turkin laatuominaisuuksia. Eläimen koko mitattiin yksilön painona ja takajalan pituutena. Turkin laatuominaisuuksia olivat turkin massakkuus, värisävyn puhtaus ja turkin peittävyys. Näiden ominaisuuksien ja kytkentäkartan välistä yhteyttä tutkittiin etsimällä kvantitatiivisen ominaisuuden lokuksia (QTL:iä). Koska kykentäkartassa merkkien välisten etäisyyksien keskiarvo on $18,6 \mathrm{cM}$, niin löydetyt QTL:t vastaavat melko laajoja kromosomialueita. Tutkimuksessa löydettiin eläimen kokoon vaikuttava kromosomialue kytkentäryhmästä S5. Kokoon vaikuttava kromosomialue löytyi sekä eläimen painolle että takajalan pituudelle samasta kromosomin kohdasta mikrosatelliittimerkkien FH2364 ja D-INRA2 välistä. Kokoon vaikuttavan QTL:n alleeleilla esiintyy sekä additiivinen vaikutus että dominanssivaikutus. Additiivisen vaikutuksen suuruus on painolle $657 \mathrm{~g}$ ja takajalan pituudelle $0,45 \mathrm{~cm}$ ja vastaavasti dominanssivaikutukset $-530 \mathrm{~g}$ ja $-0,29 \mathrm{~cm}$. Turkin massakkuuteen vaikuttavia kromosomialueita löytyi kahdesta kytkentäryhmästä S3 ja S11. Kytkentäryhmässä S3 additiivinen vaikutus on 0,20 pistettä, ja dominanssivaikutus 0,45 pistettä. Kytkentäryhmän S11 QTL:n alleelilla on vain additiivinen vaikutus massakkuuteen, ja sen suuruus on $-0,34$ pistettä. Värisävyn puhtauteen ja turkin peittävyyteen vaikuttavat kromosomialueet löytyivät kytkentäryhmistä S10 ja S4. Värisävyn puhtauteen vaikuttavan QTL:n alleelien additiivinen vaikutus ja dominanssivaikutus ovat 0,12 ja 0,16 pistettä. Turkin peittävyyden QTL:n vaikutus on pelkästään additiivinen ja sen suuruus on 0,22 pistettä.

Tehty tutkimus luo yleisesti pohjaa siniketun taloudellisesti tärkeiden ominaisuuksien taustalla olevien geneettisten tekijöiden kartoittamiselle ja ymmärtämiselle. Tässä tutkimuksessa tehty kytkentäkartta toimii perustana kaikille siniketulla tehtäville QTL -kartoitustutkimuksille, joissa voidaan analysoida muitakin kuin kokoon ja turkinlaatuun liittyviä ominaisuuksia. Jatkotutkimuksissa voidaan hyödyntää koiran genomin yksityiskohtaista informaatiota, jota on saatavilla julkisissa tietokannoissa (esimerkiksi NCBI:n ja ENSEMBL:n DNA -sekvenssitietokannoissa). Käyttämällä apuna koiran ja siniketun genomien vertailevaa tutkimusta sekä tämän tutkimuksen tuloksia olisi jatkotutkimuksissa todennäköisesti mahdollista löytää uusia siniketun kokoon ja turkinlaatuun vaikuttavia geneettisiä tekijöitä. Lisäksi tässä tutkimuksessa muodostettujen kytkentäryhmien perusteella voidaan päätellä siniketun ja koiran kromosomien evoluutiossa tapahtuneita muutoksia. 


\section{Johdanto}

Eurooppalaiset tarhaajat tuottavat valtaosan maailman tarhaturkiksista. Euroopan Unionin (EU) jäsenmaiden tarhaajat tuottavat $67 \%$ maailman minkkituotannosta ja $70 \%$ maailman kettutuotannosta (EFBA 2005). Turkistarhaus on myöskin merkittävä elinkeino Euroopassa. Eurooppalaisten turkiseläinkasvattajien kattojärjestön European Fur Breeders' Associationin (EFBA) arvioiden mukaan turkistarhojen lukumäärä oli 6500 ja näiden tarhojen tuottamien nahkojen arvo 625 miljoonaa euroa vuonna 2002. Turkisten myynnin arvo samana vuonna oli 4525 miljoonaa US dollaria (EFBA 2005). Turkiseläinten kasvatus on EU:ssa keskittynyt Suomeen, Tanskaan, Norjaan, Hollantiin, Puolaan, Viroon, Latviaan ja Liettuaan.

Suomessa turkistarhaus on merkittävä elinkeino ja maaseudun työllistäjä. Suomessa toimii 1600 turkistarhaa ja turkistuotanto työllistää suoranaisesti 6000 - 7000 ihmistä ja välillisesti alalla työskentelevät mukaan lukien yhteensä noin 10000 suomalaista (STKL 2005). Tuotannosta vientiin menee lähes $100 \%$. Esimerkiksi kaudella 2003/2004 Turkistuottajat Oyj:n huutokaupoissa myytiin 3,6 miljoonaa nahkaa. Vuosittaiset vientitulot olivat samalla kaudella 175 miljoonaa euroa (STKL 2004). Huomionarvoista turkistuotannossa on valtion tuen puuttuminen.

Suomi on maailman suurin ketunnahkojen tuottaja ja sinikettu on tärkein tarhattava laji Suomessa. Pohjoismaissa tuotetaan vuosittain noin 2,7 miljoonaa siniketun nahkaa, mikä on yli $50 \%$ maailmanmarkkinoiden siniketun nahoista. Tästä Suomen osuus on pitkään ollut yli 2 miljoonaa nahkaa. Esimerkiksi vuonna 2004 Suomen tuotanto oli 2,4 miljoonaa siniketun nahkaa (Turkistuottajat Oyj 2005).

Kotieläimillä ja viljellyillä kalalajeilla on tutkittu viimeisen kymmenen vuoden aikana runsaasti taloudellisesti tärkeiden kvantitatiivisten ominaisuuksien ja DNA-muuntelun välistä yhteyttä (Anderson \& Georges 2004, Dunham 2004). Kvantitatiivisten ominaisuuksien taustalla olevia perintötekijöitä on kartoitettu käyttäen apuna molekyyligeneettisiä merkkejä ja geneettistä kytkentäkarttaa. Merkeistä laaditun kytkentäkartan avulla etsitään kvantitatiivisiin ominaisuuksiin vaikuttavia kromosomialueita (engl. quantitative trait locus, QTL) (Mackay 2001, Doerge 2002). Tällä ns. QTL--kartoituksella pyritään ymmärtämään kvantitatiivisten ominaisuuksien taustalla olevia perintötekijöitä.

Merkkiavusteinen valinta perustuu QTL-kartoituksessa löydettyyn DNA -merkin ja ominaisuuden väliseen yhteyteen. Merkkiavusteisessa valinnassa DNA -testien avulla pyritään tehostamaan jalostuseläinten valintaa (Dekkers \& Hospital 2002, Dunham 2004). Merkkiavusteisesta valinnasta odotetaan merkittävää uutta eläinjalostuksen työvälinettä, erityisesti sellaisten ominaisuuksien jalostamisessa joiden periytymisaste on alhainen tai joiden mittaaminen on työlästä ja kallista. Esimerkiksi monet terveys- ja hedelmällisyysominaisuudet sekä lihan tai kalan laatuominaisuudet olisivat tehokkaammin jalostettavissa merkkiavusteisen valinnan avulla (Dekkers \& Hospital 2002). Turkiseläimillä esimerkiksi turkin laatuun ja hedelmällisyyteen liittyvien ominaisuuksien jalostuksessa voitaisiin hyödyntää merkkiavusteista valintaa. Turkiseläimille ei kuitenkaan toistaiseksi ole laadittu DNA-merkkeihin perustuvia kattavia kytkentäkarttoja, eikä siksi myöskään QTL-kartoitustutkimuksia ole julkaistu.

Helsingin yliopiston kotieläintieteen laitoksella aloitettiin siniketun kytkentäkartan laatimiseen ja QTL -kartoitukseen tähtäävä tutkimus vuonna 1997. Tutkimuksen rahoittajina toimivat Maa- ja metsätalousministeriö sekä Suomen Turkiseläinten Kasvattajain Liitto r.y. Tämän tutkimuksen tavoitteena oli perustaa kartoituspopulaatio ja sitä käyttäen laatia DNA -merkkeihin perustuva siniketun geneettinen kytkentäkartta. Kytkentäkarttaan perustuvassa QTL-tutkimuksessa kartoitettiin siniketun kokoon ja turkin laatuominaisuuksiin vaikuttavia kromosomialueita. Lisäksi DNAmerkkeihin perustuvan kytkentäkartan avulla voitiin arvioida koiran ja siniketun evoluutiossa tapahtuneita kromosomitason muutoksia.

\section{Aineisto ja menetelmät}

Tutkimusta varten risteytettiin kolme sukupolvea käsittävä aineisto (taulukko 1). Eläimet kasvatettiin ja mitattiin Maa- ja elintarviketalouden tutkimuskeskuksen Kannuksen tutkimusasemalla vuosina 1997-2000. F1 -polven eläimet risteytettiin kahtena peräkkäisenä vuotena ja F2 -eläimet syntyivät vuosina 1999 ja 2000. Taloudellisesti tärkeistä ominaisuuksista mitattiin eläimen kokoa ja turkin laatuominaisuuksia. Eläimen kokoa mitattiin yksilön painona ja takajalan pituutena. Eläimet punnittiin 3 ja 6 viikon iässä sekä kerran kuukaudessa elokuusta marraskuuhun. Takajalan koiven pituus mitattiin 
myös kerran kuukaudessa elokuusta marraskuuhun. Turkin laatuominaisuuksia olivat turkin massakkuus eli alusvillan tiheys, värisävyn puhtaus ja turkin peittävyys. Peittävyys kuvaa peitinkarvan osuutta pohjavillasta.

Taulukko 1. Sinikettujen risteytysaineiston eläinmäärät sukupuolittain.

\begin{tabular}{llll}
\hline Sukupolvi & Koiraat & Naaraat & Yhteensä \\
\hline P -polvi & 4 & 16 & 20 \\
F1 & 10 & 33 & 43 \\
F2 & 222 & 170 & 392 \\
Yhteensä & 236 & 219 & 455 \\
\hline
\end{tabular}

Kaikki turkin laatuominaisuudet on arvioitu asteikolla yhdestä viiteen (1=erittäin huono, $5=$ erittäin hyvä). Mitattujen ominaisuuksien riippuvuutta toisistaan arvioitiin laskemalla fenotyyppiset korrelaatiot ominaisuuksien välille.

Tutkimuksessa käytetyt DNA -merkit ovat koiralta kuvattuja mikrosatelliittimerkkejä. Testatuista 130 koiran merkistä 101 toimii siniketun DNA -näytteillä ja lisäksi yksi merkeistä monistaa kaksi lokusta (Hietanen ym. 2000). Geneettinen kytkentäkartta muodostettiin käyttäen yhteensä 50 perhettä, jotka koostuivat yhteensä 455 eläimestä (taulukko 1). F2-eläimiä oli yhteensä 392 (keskiarvo 7,8 eläintä/perhe). Kytkentäkartta laadittiin Cri-Map-ohjelmistolla (Green ym. 1990). Mikrosatelliittimerkkien etäisyydet toisistaan on ilmoitettu senttiMorganeina (cM) käyttäen Kosambin karttafunktiota.

QTL-analyysissä käytettiin 382 F2-eläimen fenotyyppitietoja. Näistä 119 oli vuoden 1999 F2eläimiä ja 263 oli vuoden 2000 F2-eläimiä. Genotyyppitiedot olivat jokaiselta eläimeltä. Takajalan koiven pituuden ja painon kohdalla päätettiin käyttää viimeisintä mittaustulosta, jolloin eläimen pentueen ja emän vaikutus ei enää ollut merkitsevä. Kytkentäkartan ja mitattujen ominaisuuksien välinen assosiaatio analysoitiin pienimmän neliösummän -menetelmällä (Haley ym. 1994) käyttäen QTL Express -ohjelmistoa (Seaton ym. 2002).

\section{Tulokset ja tulosten tarkastelu}

Laaditussa kytkentäkartassa on 87 merkkiä 17 kytkentäryhmässä ja kartan kokonaispituus on 1658 cM. Kytkentäkartat laskettiin kummallekin sukupuolelle erikseen sekä keskiarvokarttana (KeskiNisula ym. 2005). Yksittäisten kytkentäryhmien pituudet sukupuolten keskiarvokartassa vaihtelivat $4,9-322,2 \mathrm{cM}$ välillä (kuva 1 ).

Mitatut ominaisuudet ovat osittain korreloituneita (taulukko 2). Selkeimmin positiivinen korrelaatio näkyy takajalan koiven pituuden ja eläimen painon sekä turkin peittävyyden ja värisävyn puhtauden välillä. Eläimen paino ja peittävyys ovat selkeimmin negatiivisesti korreloituneita.

Taulukko 2. Fenotyyppiset korrelaatiot F2-polvessa ( $\mathrm{N}=408)$.

\begin{tabular}{lllll}
\hline Ominaisuus & Paino & $\begin{array}{l}\text { Takajalan } \\
\text { pituus }\end{array}$ & Massakkuus & $\begin{array}{l}\text { Värisävyn } \\
\text { puhtaus }\end{array}$ \\
\hline Takajalan pituus & $0.58^{* * *}$ & & & \\
Massakkuus & $0.40^{* * *}$ & 0.03 & & \\
Värisävyn puhtaus & $-0.10^{*}$ & $-0.12^{*}$ & $0.22^{* * *}$ & \\
Peittävyys & $-0.21^{* * *}$ & $-0.18^{* *}$ & $0.13^{* *}$ & $0.58^{* * *}$ \\
\hline
\end{tabular}

$* * * \mathrm{p} \leq 0,001, * * \mathrm{p} \leq 0,01,{ }^{*} \mathrm{p}<0,05$

Painolle ja takajalan pituudelle löytyi QTL kytkentäryhmästä S5 (taulukko 3). Näistä kahdesta takajalan pituudelle löydetty QTL sai kaikista QTL:stä korkeimman testisuureen arvon $(F=20,45)$. Painon ja takajalan pituuden QTL:t sijaitsevat käytännössä samassa kohdin kromosomia, ja mahdollisesti niiden taustalla on sama eläimen kokoon vaikuttava suurivaikutteinen geeni (tai geenejä). Turkin peittävyydelle löydettiin QTL kytkentäryhmästä S4 ja turkin värisävyn puhtaudelle kytkentäryhmästä S10. Turkin massakkuudelle löytyi kaksi QTL, kytkentäryhmistä S3 ja S11. Painoon, takajalan koiven pituuteen sekä turkin peittävyyteen vaikuttavien alleelien additiivinen vaikutus oli suurempi kuin dominanssivaikutus. Värisävyn puhtauteen vaikuttavien alleelien 
Kuva 1. Siniketun kytkentäkartta sukupuolittain ja sukupuolten välinen keskiarvokartta.

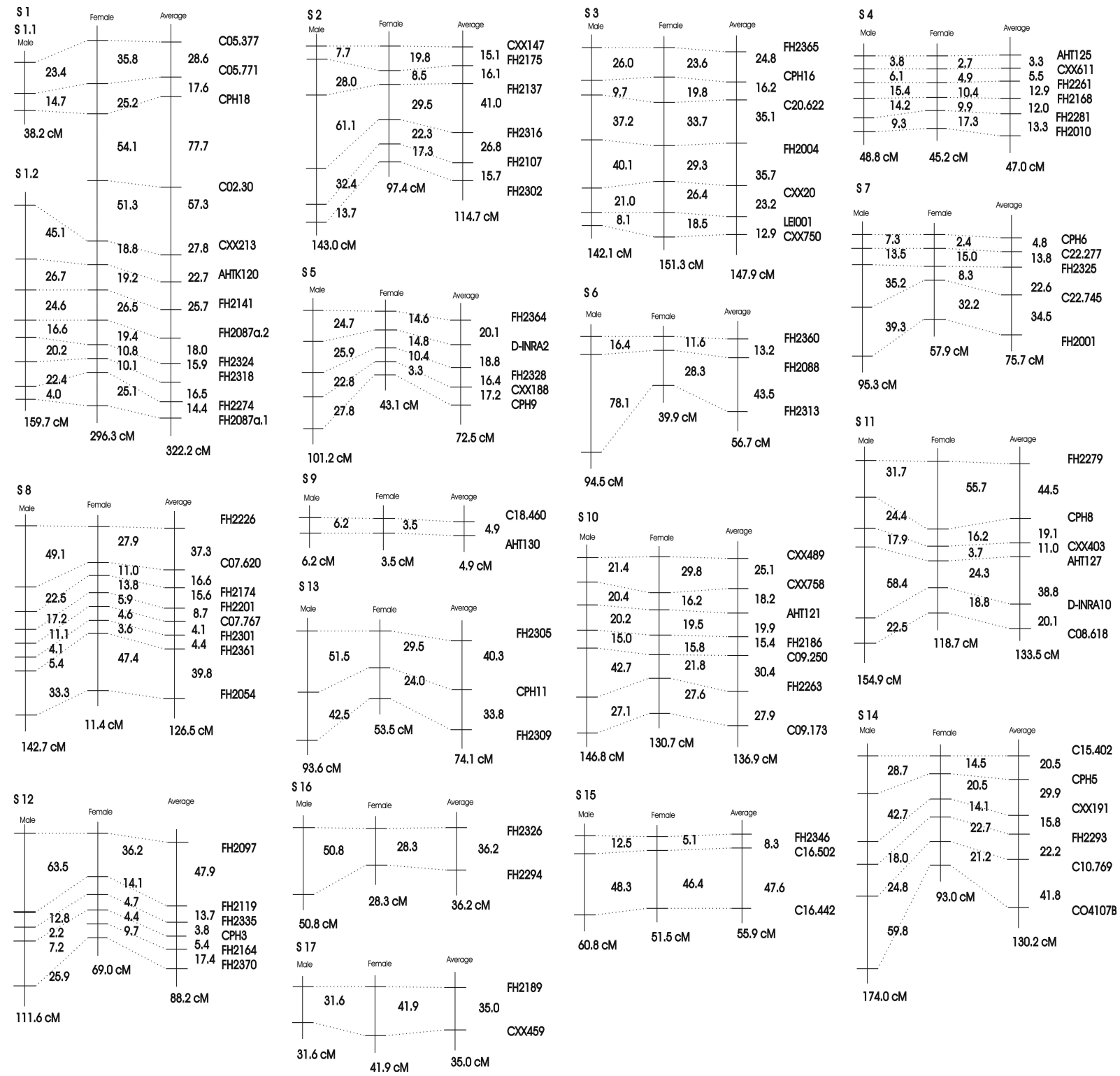

dominanssivaikutus oli additiivista vaikutusta suurempi. Turkin massakkuuteen kytkentäryhmässä S3 vaikuttavien alleelien dominanssivaikutus oli additiivista vaikutusta suurempi, mutta kytkentäryhmässä S11 massakkuuden QTL:n alleeleilla esiintyy vain additiivinen vaikutus (taulukko 3). Osa löydettyjen QTL:ien alleeleista saattaa olla tämän perusteella täydellisesti dominantteja.

Taulukko 3. Löydettyjen QTL:ien sijainti kytkentäryhmissä (suluissa lähimmät mikrosatelliittimerkit), F-arvot sekä additiiviset vaikutukset ja dominanssivaikutukset.

\begin{tabular}{lllrrr}
\hline Ominaisuus & $\begin{array}{l}\text { Kyt- } \\
\text { kentä- } \\
\text { ryhmä }\end{array}$ & QTL:n sijainti (cM) & \multicolumn{1}{l}{$\begin{array}{l}\text { F- } \\
\text { arvo }\end{array}$} & \multicolumn{1}{l}{$\begin{array}{l}\text { Add. vaikutus } \\
\text { (SE) }\end{array}$} & \multicolumn{1}{l}{$\begin{array}{l}\text { Dom. vaikutus } \\
\text { (SE) }\end{array}$} \\
\hline Takajalan pituus (cm) & S 5 & 4 (FH2364 ja D-INRA2) & 20,45 & $0,445(0,077)$ & $-0,288(0,118)$ \\
Paino (g) & S 5 & 1 (FH2364 ja D-INRA2) & 11,66 & $656,7(159,9)$ & $-529,8(233,6)$ \\
Massakkuus & S 11 & 99(AHT127 ja D-INRA10) & 8,16 & $-0,340(0,085)$ & $-0,015(0,161)$ \\
Värisävyn puhtaus & S 10 & 60 (FH2186 ja C09.250) & 8,02 & $0,118(0,039)$ & $0,157(0,060)$ \\
Peittävyys & S 4 & 22 (FH2168) & 7,85 & $0,215(0,055)$ & $0,087(0,077)$ \\
Massakkuus & S 3 & 100(FH2004 ja CXX20) & 7,76 & $0,201(0,081)$ & $0,450(0,151)$ \\
\hline
\end{tabular}


Tässä tutkimuksessa tehdyn merkkikartan ja Graphodatskyn ym. (2000) sytogeneettisten tutkimusten pohjalta voidaan arvioida siniketun ja koiran kromosomien evoluutiota ja homologisten kromosomien osien vastaavuutta. Lajien välillä havaittava ero kromosomien lukumäärissä, siniketulla $2 \mathrm{n}=48-50$ ja koiralla $2 \mathrm{n}=78$, selittyy pitkälti kromosomien fuusioitumisella. Monissa tapauksissa kaksi koiran kromosomia esiintyy yhdessä siniketun kytkentäryhmässä. Esimerkiksi koiran kromosomit 3 (CFA3) ja 16 (CFA16) sijoittuvat siniketun kytkentäryhmään S2, ja CFA11 ja CFA20 sijoittuvat kytkentäryhmään S3. Lisäksi havaitaan, että merkkien järjestys on lajien välillä pitkälti säilynyt samana.

\section{Johtopäätökset}

Tehty tutkimus luo pohjaa yleisesti siniketun taloudellisesti tärkeiden ominaisuuksien taustalla olevien geneettisten tekijöiden kartoittamiselle ja ymmärtämiselle. Tässä tutkimuksessa tehty kytkentäkartta toimii perustana kaikille siniketulla tehtäville QTL-kartoitustutkimuksille. Tämän tutkimuksen tuloksina löytyi neljälle taloudellisesti tärkeälle ominaisuudelle assosiaatio tiettyyn siniketun kromosomialueeseen. Näiden kromosomialueiden tarkempi kartoitus voi johtaa siniketun kokoon ja turkinlaatuun vaikuttavien geneettisten tekijöiden löytymiseen DNA -tasolla. DNA -tason tiedolla pystyttäisiin tehostamaan siniketun valintajalostusta. Lisäksi tässä tutkimuksessa laaditusta kytkentäkartasta voidaan päätellä, että käytettyjen mikrosatelliittimerkkien kytkentä on evoluutiossa pitkälti säilynyt samana siniketun ja koiran välillä. Lajien välillä havaittava ero kromosomien lukumäärissä selittyy pitkälti kromosomien fuusioitumisella.

\section{Kirjallisuus}

Anderson, L. \& Georges, M. 2004. Domestic-animal genomics: deciphering the genetics of complex traits. Nature Reviews Genetics 5: 202-212.

Dekkers, J.C.M. \& Hospital, F. 2002. The use of molecular genetics in the improvement of agricultural populations . Nature Reviews Genetics 3: 22-32.

Doerge, R. 2002. Mapping and analysis of quantitative trait loci in experimental populations. Nature Reviews Genetics 3: 43-52

Dunham, R.A. 2004. Aquaculture and Fisheries Biotechnology. CABI Publishing. 372 s.

EFBA. 2005. European Fur Breeders' Association, verkkosivut, http://www.efbanet.com/, 20.10.2005 mukaisesti.

Graphodatsky, A.S., Yang, F., O'Brien, P.C.M., Serdukova, N., Milne, B.S., Trifonov, V. \& FergusonSmith, M.A. 2000. A comparative chromosome map of the Arctic fox, red fox and dog defined by chromosome painting and high resolution G-banding. Chromosome Research 8: 253-263.

Green, P., Falls, K. \& Crooks, S. 1990. Cri-Map, version 2.4. Department of Genetics, Washington University School of Medicine, St. Louis, Missouri.

Haley, C.S., Knott, S.A. \& Elsen, J.M. 1994. Mapping quantitative trait loci in crosses between outbred lines using least squares. Genetics 136: 1195-1207.

Hietanen, H., Tähtinen, J., Ojala, M., Rintamäki, M. \& Niemelä, P. 2000. DNA -mikrosatelliittien käyttö sinikettujen geenikartoituksessa. Maataloustieteen päivät, Maaseutukeskusten liiton julkaisuja no 952, s. $207-$ 210.

Keski-Nisula, S., Elo, K., Tähtinen, J. \& Ojala, M. 2005. A genetic linkage map of the blue fox (Alopex lagopus). Tiivistelmä, 56 ${ }^{\text {th }}$ Annual Meeting of the European Association for Animal Production, 5.-8.6.2005, Uppsala, Sweden. Book of Abstracts no 11, s. 100.

Mackay, T.F.C. 2001. The genetic architecture of quantitative traits. Annual Reviews of Genetics 35: 303-339.

Seaton G., Haley C.S., Knott S.A., Kearsey M. \& Visscher P.M. 2002. QTL Express: mapping quantitative trait loci in simple and complex pedigrees. Bioinformatics 18: 339-340.

STKL. 2004. Toimintakertomus 2004. Suomen Turkiseläinten Kasvattajain Liitto r.y. 34 s.

STKL. 2005. Suomen Turkiseläinten Kasvattajain Liitto r.y:n verkkosivut, http://www.stkl-fpf.fi/, valikko "Tilastotietoja". 20.10.2005 mukaisesti.

Turkistuottajat Oyj. 2005. Verkkosivut http://www.ffs.fi, valikko "Avainlukuja ja tilastoja", 25.10.2005 mukaisesti. 